\title{
The Relationship Between Spatial Patterns of Urban Land Uses and Air Pollutants in the Tehran Metropolis, Iran
}

\section{Soheil Gheshlaghpoor}

University of Tehran

\section{Seyedeh Sanaz Abedi}

University of Science and Technology

masoumeh moghbel ( $\nabla$ moghbel@ut.ac.ir)

University of Tehran https://orcid.org/0000-0001-9393-9954

\section{Research Article}

Keywords: Land Use, Air Pollutants, Landscape Metrics, Local Climate Zone, Tehran Metropolis.

Posted Date: January 31st, 2022

DOl: https://doi.org/10.21203/rs.3.rs-1246864/v1

License: (c) (i) This work is licensed under a Creative Commons Attribution 4.0 International License.

Read Full License 


\section{Abstract}

Context: Urban expansion has led to land use changes in metropolises, which in turn cause landscape pattern changes and intensive ecological issues in urban areas.

Objective: The main objective of this research is to investigate the relationship between different land use patterns and air pollutants $\left(\mathrm{NO}_{2}, \mathrm{SO}_{2}, \mathrm{CO}, \mathrm{O}_{3}\right)$ in the metropolis of Tehran.

Method:The Local Climate Zone (LCZ) scheme and Landsat 8 satellite images were used to extract urban land uses in Tehran. Additionally, Sentinel-5P satellite images were used to calculate and evaluate air pollutants in summer (2020) and winter (2021).Then, the relationship between the spatial composition and configuration of urban land uses and air pollutants was computed using Pearson correlation coefficient and multiple linear regression in summer 2020 and winter 2021.

Results: The results indicate that the distribution or concentration of air pollutants is different from the spatial pattern of land use. The spatial composition and configuration of man-made land uses, including the classes of compact mid-rise, compact low-rise, large low-rise, and heavy industry, had a positive correlation with $\mathrm{NO}_{2}$ and $\mathrm{SO}_{2}(\mathrm{Sig}<0 / 038)$. In contrast, the pollutant $\mathrm{CO}$ had a significant negative correlation with the green spaces of types A (dense trees) (Sig: 0/004, (99\%)) and B (scattered trees) (Sig: 0/034, (95\%)). Conversely, the spatial composition and configuration of man-made land uses had a negative correlation with $\mathrm{O}_{3}(\mathrm{Sig}<0 / 047)$ while had a positive correlation with green spaces $(\mathrm{Sig}<0 / 047)$.

Conclusion: The obtained results show that quantitative analysis can help to develop more complex strategies and scenarios in future research.

\section{Introduction}

Climate warming is a global issue, which has become a serious threat to human health and the environment (Ou et al., 2013). One of the main reason of climate warming is increasing trend in greenhouse gases emissions especially after industrialization era which has captured the attention of most of the world's nations(Parry et al., 2007). Urban centers are key players in generating greenhouse gases (Moghbel \& Erfanian Salim, 2017). The most common air pollutants in cities include carbon monoxide(CO), sulfur dioxide(SO2), nitrogen oxides(NOx), hydrocarbons(HC), suspended particulate matter (SPM, including PM10, PM2.5), ozone(03) (Hoek et al., 2002). Urban development and it's structure, public facilities and traffic patterns are the main factors which can deteriorate of urban air quality. In other word, land use and transportation modes have been changed due to urbanization so that significant increase in energy consumption and the massive emission of air pollutants have exacerbated the current state of air pollution(Fang et al., 2015; Hopke et al., 2008; She et al., 2017).

Rapid urbanization also results in expansion of small urban centers to their original individual boundaries. Merging of small urban centers into each other cause to formation of huge conurbations of urban centers. In this regard, changes in land use along with traffic and industrial emissions, have also 
been identified as a main reason which can affect urban air quality(Huang et al., 2013; Romero et al., 1999; Weng \& Yang, 2006; Xu et al., 2016; Zahari et al., 2016). Urban land use patterns are usually reflected via the dispersion of air pollutants and air quality in urban environments(Huang \& Du, 2018). In fact, distribution of pollutants depend on the activities of the land use(Halim et al., 2020). Therefore, deterioration of urban air quality is appeared as an tremendous stress sign due to the rising patterns of land use changes(Du et al., 2010; Hien et al., 2020; Huang \& Du, 2018; Tao et al., 2015; Wei \& Ye, 2014).

Land use changes affect natural land cover surfaces directly or indirectly in this way it can influence the transport/dispersion of air pollution(Halim et al., 2020). It has been well documented in previous studies that urban building layouts, urban planning patterns, building height, and other factors can affect the air quality in urban environments(Gómez-Baggethun \& Barton, 2013; Ng, 2009). Hence, air pollution can concentrated in built-up lands(Wang et al., 2018; Weng \& Yang, 2006; Xian, 2007; Zahari et al., 2016). Accordingly,Weng and Yang (2006) examined the impact of land use variables on air pollutants. They showed a positive correlation between spatial trends of air pollutants with the density of built-up land in Guangzhou, China. Also, $\mathrm{Ku}(2020)$ have illustrated that the annual averages $\mathrm{NO}_{2}$ is increased by increase of built-up area in Tiachung city, Taiwan. Whereas inverse relationship was observed between the increase in forest connectivity and forest area and annual average of $\mathrm{NO}_{2}$. Liu and Shen (2014) have indicated a negative correlation between green spaces and air pollution. Zhu et al. (2019) have represented that concentrations of $\mathrm{SO}_{2}, \mathrm{CO}$ and $\mathrm{O}_{3}$ were all positively correlated with the cultivated land. Similarly, foresty lands lead to decrease of $\mathrm{SO}_{2}$ and $\mathrm{CO}$ concentration. Furthermore, a positive correlation has been found between cultivated land with many air pollutants by Huang and Du (2018), while Nowak et al. (2006) found that there is low concentration of air pollutants in forestry land. Base on a study which conducted by Nowak et al. (2000) local ozone concentrations can reduce by increase of tree covers in urban area by a few parts per billion ( $\mathrm{ppb}$ ) by volume during daytime.

The studies mentioned above show that there is is considerable relationship between urban land use and changes in air pollutants. However, most previous studies have examined this relationship using the maps of current urban land use conditions and data from air quality monitoring stations. Air pollution has become one of the most tangible environmental problems in cities due to harmful problems caused by it. The city of Tehran is no exception to this rule and due to the increase in such pollutants of sulfur dioxide and carbon monoxide, the number of respiratory patients has increased by $60 \%$. Thus, to achieve a deeper understanding of the effectiveness of urban air quality improvement strategies (reducing air pollution), it is nessesary to use integrated research methods such as the quantification of the spatial structure of urban patterns (composition and configuration) and the analysis of the correlation between air pollutants and land (Ku, 2020). Accordingly, a spatial-temporal analysis based on the spatial structure of urban patterns (composition and configuration) was conducted in this study. It is included the analysis of the relationship between the spatial composition and configuration of urban land uses and air pollutants using Pearson correlation coefficient and multiple linear regression, respectively, in summer and winter. The purpose of this study was to investigate the relationship between different land use 
patterns and air pollutants and answer the question of what is the relationship between the spatial patterns of urban land uses and air pollutants in summer and winter?

\section{Methodology}

In the present study, the Local Climate Zone (LCZ) scheme and Landsat 8 satellite images were used to extract urban land uses in Tehran. Then, FRAGSTATS software (version 4.2.1) was used to calculate land use metrics based on spatial patterns (composition and configuration) of each land use. Additionally, Sentinel-5P satellite images were used to calculate and evaluate air pollutants in summer (2020) and winter (2021). Finally, considering 22 districts of Tehran, Pearson correlation coefficient and multiple linear regression were used to investigate the relationship between the spatial composition and configuration of urban land uses and air pollutants, respectively (Fig. 1). It should be noted that land use maps were generated at the same scale used to generate the images for air pollutants, namely $1 \mathrm{~km}$.

\section{1. The Case Of Study}

Tehran as the most populous metropolis of Iran is located in the geographical position of $35^{\circ} 36^{\prime} 46^{\prime \prime} \mathrm{N}$ and $51^{\circ} 17^{\prime} 23^{\prime \prime} \mathrm{E}$. The area of the city is equal to 730 square kilometers and its population is about 9 million people, so it has the highest population density in Iran with a population density of 12,910 people per square kilometer. Tehran now has 22 regions (Fig. 2) and is the 25th most populous city and the 27th largest city in the world (www.tehran.ir). Due to the rapid population growth and increasing urbanization, the metropolis of Tehran includes various types of urban land uses. Additionally, the special geographical location of the city, which is surrounded by Shemiran heights in the north, Damavand in the east, and Karaj in the west and is open only from the south, has led to the increased concentration of pollutants in this metropolis (Zebardast \& Riazi, 2015). It is ranked 27th in 2019 among the most polluted cities in the world (https://www.iqair.com/iran/tehran). Thus, to investigate the relationship between urban land uses and air pollution, the metropolis of Tehran was considered as the study case in the present research.

\section{2. Methods}

The local climate zone (LCZ) scheme was used to extract urban land uses. The LCZ scheme is currently considered as a standard for linking landscape to air pollutants at an urban scale. Generally, this classification scheme can be applied in three areas: 1. study of urban heat islands (Alexander \& Mills, 2014; Emmanuel \& Krüger, 2012; Leconte et al., 2015; Lehnert et al., 2015), 2. Modeling (Alexander et al., 2015; Bokwa et al., 2015; Geletič et al., 2016), and 3. extraction of land cover maps based on different geometric features (Bechtel \& Daneke, 2012; Danylo et al., 2016; Lelovics et al., 2014). One of the advantages of LCZ classification is the complete description of land-use types in an urban environment because it meets the standards for measuring physical properties and urban morphology (Stewart \& Oke, 2010). This classification divides urban land uses into 10 types of man-made and built spaces (1-10) and 7 types of natural land cover (A-G) (Fig. 3)(Stewart \& Oke, 2012). Each class can be identified using 
structural features and land cover that influence air temperature at a height of 1-2 meters above the ground (Das \& Das, 2020). One of the methods for generating a map based on the LCZ classification is the remote sensing imagery-based method (Bechtel et al., 2016; Lin \& Xu, 2016). Using this method, we followed three basic steps of pre-processing Landsat-8 satellite images (TM \& OLI / TIR) (Summer, 2020; Winter, 2021) by SagaGIS software(Conrad et al., 2015), digitization of each class of land uses by Google Earth, and the classification of land uses based on the LCZ schema by SAGA GIS software.

After producing the classification maps based on the LCZ schema, we matched the detected data with the Google Earth map related to the time of extraction by ENVI5.3 software. Thus, we checked the classification accuracy using the kappa coefficient and overall accuracy. If the Kappa coefficient is above $85 \%$ and the overall accuracy is above $90 \%$ at this stage, the accuracy of the generated map can be considered acceptable (Kerle et al., 2004).

\section{3. Selected Metrics}

After generating land use maps, the characteristics of the land uses were quantified using landscape metrics and the calculations were performed by FRAGSTATS 4.2 .1 software. As Table(1) shows, 6 metrics with the following characteristics were selected: 1 . significant role in theory and practice (Li \& Wu, 2004; Peng et al., 2010; Zhou et al., 2011), 2. Ease of calculation and high interpretive power (Li et al., 2012; Zhou et al., 2011), and 3. The least exaggeration in the data (Li \& Wu, 2004; Riitters et al., 1995; Zhou et al., 2011).

Table 1. Definitions of landscape metrics selected in this study(McGarigal, 2015)

\begin{tabular}{|c|c|c|c|}
\hline Categories & $\begin{array}{c}\text { Metrics } \\
\text { (abbreviation) }\end{array}$ & Description & Equation \\
\hline $\begin{array}{l}\text { Compsitio } \\
\mathrm{n}\end{array}$ & $\begin{array}{l}\text { Class area } \\
\text { (CA) }\end{array}$ & total class area(unit: Hectares) & $\sum_{j=1}^{\infty} a_{i j}(1 / 1000)$ \\
\hline \multirow{5}{*}{$\begin{array}{l}\text { Configurat } \\
\text { ion }\end{array}$} & $\begin{array}{l}\text { Mean Patch Area } \\
\text { (AREA_MN) }\end{array}$ & $\begin{array}{l}\text { Total patch area divided by patch number } \\
\text { (units: Hectares) }\end{array}$ & $\left(\sum_{f=1}^{n} a_{i j} / n_{i}\right)(1 / 10000$ \\
\hline & $\begin{array}{l}\text { Patch Density } \\
\text { (PD) }\end{array}$ & $\begin{array}{c}\text { Number of patches divided by total landscape } \\
\text { area } \\
\text { (unit: number per } \mathrm{km} 2 \text { ) }\end{array}$ & $\frac{n_{i}}{A}(10000)(100)$ \\
\hline & $\begin{array}{l}\text { Edge density } \\
\text { (ED) }\end{array}$ & $\begin{array}{l}\text { Amount of edge relative to the landscape area at } \\
\text { class level (unit: } \mathrm{m} / \mathrm{ha} \text { ) }\end{array}$ & $\frac{\sum_{k=1}^{m} e_{i k}}{A}(10000)$ \\
\hline & $\begin{array}{l}\text { Largest Patch } \\
\text { Index } \\
\text { (LPI) }\end{array}$ & $\begin{array}{l}\text { Percent of the total landscape that is made up by } \\
\text { the largest patch at class level (unit: \%) }\end{array}$ & $\frac{\max \left(a_{i j}\right)}{A}(100)$ \\
\hline & $\begin{array}{l}\text { Area-Weighted } \\
\text { Radius } \\
\text { of Gyration } \\
\text { (GYRATE_AM) }\end{array}$ & $\begin{array}{c}\text { The mean distance }(\mathrm{m}) \text { between each cell in the } \\
\text { patch and thepatch centroid divided by the sum } \\
\text { of patch areas. } \\
\text { (unit:Meters) }\end{array}$ & $\left.z)\left(a_{i j} / \sum_{j=1}^{\mathrm{n}} a_{i j}\right)\right]$ \\
\hline
\end{tabular}

$\mathrm{a}_{\mathrm{ij}}=$ area $(\mathrm{m})$ of patch $\mathrm{j} ; \mathrm{n}_{\mathrm{i}}=$ number of patches; $\mathrm{A}=$ total landscape; $\mathrm{e}_{\mathrm{ik}}=$ total; $\mathrm{h}_{\mathrm{ij}}=$ distance between cell $\mathrm{ijr} ; \mathrm{z}=$ number of cells 
A wide range of studies have evaluated air pollution using satellite images at various scales (AlvarezMendoza et al., 2019; Basu et al., 2019; Fernández-Pacheco et al., 2018; Meng et al., 2016; Zhang et al., 2019). One of the satellites used for this purpose is Sentinel-5P (Table 2). It is an earth observation satellite that was launched on 13 October 2017 by the European Space Agency for the global monitoring of the environment and the air pollutants such as carbon dioxide, nitrogen dioxide, ozone, and sulfur dioxide with a resolution of $1 \mathrm{~km} * 1 \mathrm{~km}$ and a very high speed (Sannigrahi et al., 2020; Veefkind et al., 2012). In this study, the spatial and temporal variation of air pollutants was investigated using the Sentile-5P satellite and its TROPOMI instruments on the Google Earth Engine (GEE) platform. GEE is a geographic data processor launched by Google in 2010 that allows users to access GEE through an Internet-based Application Programming Interface (API) and an interactive web-based development environment (Amani et al., 2020).

Table 2

Sentile-5P satellite information about air pollutants

\begin{tabular}{|c|c|c|c|c|c|}
\hline Satellite & Name & Description & Min* & Max* & Unit \\
\hline \multirow{4}{*}{$\begin{array}{l}\text { Sentinel- } \\
5 p\end{array}$} & $\mathrm{CO}$ & Vertically integrated $\mathrm{CO}$ column density & -279 & 4.64 & \multirow[t]{4}{*}{$\mathrm{mol} / \mathrm{m}^{\wedge} 2$} \\
\hline & $\mathrm{NO}_{2}$ & $\begin{array}{l}\text { Total vertical column of } \mathrm{NO}_{2} \text { (ratio of the slant } \\
\text { column density of } \mathrm{NO}_{2} \text { and the total air mass } \\
\text { factor). }\end{array}$ & -0.0006 & 0.0096 & \\
\hline & $\mathrm{SO}_{2}$ & $\begin{array}{l}\mathrm{SO}_{2} \text { vertical column density at ground level, } \\
\text { calculated using the DOAS technique. }\end{array}$ & -48 & 0.24 & \\
\hline & 03 & $\begin{array}{l}\text { Total atmospheric column of } 03 \text { between the } \\
\text { surface and the top of atmosphere, calculated } \\
\text { with the [DOAS algorithm] }\end{array}$ & 0.0047 & 0.272 & \\
\hline
\end{tabular}

\section{Results}

\subsection{Extraction of land uses and air pollutants in Tehran metropolis}

Using Landsat 8 satellite, land use maps were generated with the help of LCZ schema for the summer 2020 and winter 2021. Land uses were classified into 8 types, including compact buildings of 3-9 stories and more (2), compact buildings of 1-3 stories (3), large industrial warehouses (8), industrial structures (10), dense coniferous/deciduous trees with green ground cover (A), scattered coniferous/deciduous trees with green ground cover (B), scattered bush and scrub with green ground cover (C), low plants without/ with scattered bushes and green ground cover (mostly agricultural lands) (D). Kappa coefficient and overall accuracy were obtained respectively to be 0.8603 and $87.23 \%$ for the map of summer 2020 and 0.8706 and $88.17 \%$, for the map of winter 2021 , indicating the accuracy of the maps generated. On the other hand, according to the measurement of air pollutants and Figure(4) which shows the trend of 
changes in air pollutants, the trend of changes in $\mathrm{CO}$ and $\mathrm{O}_{3}$ was declining in summer so that the maximum and minimum density of these pollutants were (0.0350), (0.1262) and (0.03295), (0.1238) $\mathrm{mol} / \mathrm{m}^{2}$, respectively. In contrast, changes in $\mathrm{NO}_{2}$ showed an increasing trend in summer, with a maximum density of $(0.00046)$ and a minimum density of $(0.00035) \mathrm{mol} / \mathrm{m}^{2}$. In winter, changes in the three pollutants $\mathrm{CO}, \mathrm{SO}_{2}$, and $\mathrm{NO}_{2}$, in contrast to $\mathrm{O}_{3}$, showed a sharply declining trend with the maximum density of (0.0033), (0.0008), and $(0.058) \mathrm{mol} / \mathrm{m}^{2}$ and the minimum density of $(0.0001),(0.0004)$, and $(0.0355) \mathrm{mol} / \mathrm{m}^{2}$, respectively.

\subsection{The relationship between the spatial composition of urban land uses and air pollutants}

Pearson correlation coefficient was used to investigate the relationship between the spatial composition of urban land uses and air pollutants. Table (3) shows the correlation coefficients between the CA metric of the eight types of land uses defined for Tehran and the pollutants $\mathrm{NO}_{2}, \mathrm{SO}_{2}, \mathrm{CO}$, and $\mathrm{O}_{3}$. The results showed that $\mathrm{CO}$ and $\mathrm{NO}_{2}$ had a significant positive correlation with built land uses (compact midrise (2), compact low-rise (3), large low-rise (8), and heavy industry (10)) at $95 \%$ and $99 \%$ confidence levels (Sig<0/038). In contrast, while having a significant negative correlation with green spaces of types $A$ (dense trees) (Sig: 0/004) and B (scattered trees) (Sig: 0/034) in both seasons, the pollutant CO had a significant negative correlation with the green spaces of type $D$ (low plants) (Sig: 0/048) in summer. It should be noted that in addition to the negative correlations mentioned for $\mathrm{CO}$, the pollutant $\mathrm{NO}_{2}$ had also a significant negative correlation with the green spaces of type $C$ (scattered bush and scrub) (Sig: 0/042) in summer.

The pollutant $\mathrm{SO}_{2}$ had a significant positive correlation with compact buildings of 3-9 stories and more, large industrial warehouses, and industrial structures in both seasons $(0 / 001<\mathrm{Sig}<0 / 02)$, and it had a significant positive correlation with compact buildings of 1-3 stories (Sig: 0/043) only in winter. This pollutant had a significant negative correlation with green spaces including dense and scattered trees in both seasons $(0 / 003<\mathrm{Sig}<0 / 032)$ and the lands including bushes, grasslands and agricultural lands in summer at $95 \%$ and $99 \%$ confidence levels. The correlations obtained in relation to the pollutant $\mathrm{O}_{3}$ were in contrast to the correlations of other pollutants. This pollutant had a significant negative correlation with compact buildings of 3-9 stories, large industrial warehouses, and industrial structures $(\mathrm{Sig}<0 / 047)$, and a significant positive correlation with green spaces including scattered trees and green ground cover in both seasons $(0 / 043<\mathrm{Sig}<0 / 047)$ and the green spaces including dense trees, grasslands, and agricultural lands in summer $(0 / 006<\mathrm{Sig}<0 / 041)$. Among the pollutants, the average concentration of the pollutant $\mathrm{O}_{3}(-0.612)$ in summer and the average concentration of the pollutant $\mathrm{CO}(0.621)$ in winter had the highest correlation with the composition of land uses.

Considering the land uses, the CA metric of lands with natural cover (dense trees $(A)$, scattered trees $(B)$, bush and scrub (C), low plants (D)) had a negative correlation with the concentration of air pollutants except $\mathrm{O}_{3}$. In other words, the larger the area of these lands, the lower the concentration of air pollutants. 
In contrast, the CA metric of built and man-made land uses (compact midrise (2), compact low-rise (3), large low-rise (8), and heavy industry (10)) had a positive correlation with the concentration of all pollutants except $\mathrm{O}_{3}$ so that the concentration of pollutants increased with the increase in the area of these land uses. It should be noted that the CA metric of compact midrise (summer) and heavy industry (winter) had the highest correlation with the concentration of air pollutants.

Table 3 correlation coefficients between the CA metric and air pollutants

\begin{tabular}{|c|c|c|c|c|c|c|c|c|}
\hline \multirow[t]{2}{*}{ land use } & \multicolumn{4}{|c|}{ CA of Summer 2019} & \multicolumn{4}{|c|}{ CA of Winter 2020} \\
\hline & $\mathrm{CO}$ & $\mathrm{SO}_{2}$ & $\mathrm{NO}_{2}$ & $\mathrm{O}_{3}$ & $\mathrm{CO}$ & $\mathrm{SO}_{2}$ & $\mathrm{NO}_{2}$ & $\mathrm{O}_{3}$ \\
\hline 2 & $0.487^{* *}$ & $0.363^{*}$ & $0.549^{\star \star}$ & $-0.612^{\star \star}$ & $0.541^{\star \star}$ & $0.424^{*}$ & $0.591^{\star \star}$ & $-0.443^{*}$ \\
\hline Sig & 0.006 & 0.048 & 0.002 & 0.00 & 0.002 & 0.002 & 0.001 & 0.014 \\
\hline 3 & $0.407^{\star}$ & 0.299 & $0.476^{* *}$ & $-0.437^{\star}$ & $0.435^{*}$ & $0.372^{\star}$ & $0.513^{\star \star}$ & $-0.425^{*}$ \\
\hline Sig & 0.026 & 0.108 & 0.008 & 0.016 & 0.016 & 0.043 & 0.004 & 0.019 \\
\hline 8 & $0.381^{*}$ & $0.482^{* *}$ & $0.411^{*}$ & -0.266 & $0.533^{* *}$ & $0.438^{* *}$ & $0.524^{\star \star}$ & -0.239 \\
\hline Sig & 0.038 & 0.007 & 0.024 & 0.156 & 0.002 & 0.015 & 0.003 & 0.196 \\
\hline 10 & $0 / 482^{* *}$ & $0.566^{* *}$ & $0.524^{\star *}$ & $-0.380^{*}$ & $0.621^{* *}$ & $0.516^{* *}$ & $0.619^{\star \star}$ & $-0.353^{*}$ \\
\hline Sig & 0.007 & 0.001 & 0.003 & 0.038 & 0.00 & 0.004 & 0.00 & 0.047 \\
\hline A & $-0.515^{\star \star}$ & $-0 / 520^{\star \star}$ & $-0.519^{\star \star}$ & $0.379^{*}$ & $-0.482^{\star \star}$ & $0.487^{\star \star}$ & $-0.525^{\star \star}$ & $0.459^{\star \star}$ \\
\hline Sig & 0.004 & 0.003 & 0.003 & 0.039 & 0.007 & 0.006 & 0.003 & 0.008 \\
\hline B & $-0.395^{\star}$ & $-0.496^{\star *}$ & $0.478^{* \star}$ & $0.343^{*}$ & $-0.371^{*}$ & $-0.392^{*}$ & $-0.446^{*}$ & $0.360^{*}$ \\
\hline Sig & 0.034 & 0.005 & 0.008 & 0.047 & 0.044 & 0.032 & 0.013 & 0.043 \\
\hline C & -0.282 & $-0.376^{*}$ & $-0.376^{*}$ & $0.352^{*}$ & -0.262 & -0.256 & -0.322 & $0.324^{*}$ \\
\hline Sig & 0.138 & 0.041 & 0.042 & 0.041 & 0.162 & 0.173 & 0.083 & 0.044 \\
\hline D & $-0.352^{*}$ & $-0.532^{\star \star}$ & $0.368^{*}$ & $0.493^{* *}$ & -0.174 & -0.299 & -0.272 & 0.187 \\
\hline Sig & 0.048 & 0.002 & 0.045 & 0.006 & 0.358 & 0.109 & 0.0147 & 0.305 \\
\hline
\end{tabular}

\subsection{The relationship between the spatial configuration of urban land uses and air pollutants}

The relationship between the spatial configuration of land uses and the air pollutants in Tehran was studied using 5 metrics of AREA_MN, PD, ED, LPI, and GYRATE_AM and multiple linear regression in 
which the dependent variable $Y$ indicated the average change of air pollutants in summer and winter and the independent variable $X$ indicated the metrics selected for different land uses. After examining the regression models that had reached a significant level, it was found that $\mathrm{CO}$ had a significant positive correlation with the AREA_MN, PD, and ED metrics of compact buildings of 1-3 stories, the AREA_MN, PD, and LPI metrics of industrial warehouses, and the PD, ED, LPI, and GYRATE_AM metrics of compact buildings of 3-9 stories and industrial structures in summer. This correlation was also seen for this pollutant in winter so that it had a significant positive correlation with the AREA_MN, PD, ED, and LPI metrics of compact buildings of 3-9 stories, the AREA_MN and PD metrics of compact buildings of 1-3 stories, and the AREA_MN, PD, and LPI metrics of industrial structures. Regarding the relationship between this pollutant and natural land uses, it was recognized that $\mathrm{CO}$ had a negative correlation with AREA_MN, PD, and ED metrics of green spaces including dense and scattered trees in summer and winter. It had also the same relationship with the AREA_MN and GYRATE_AM metrics of agricultural lands in summer. The pollutant $\mathrm{SO}_{2}$ had a significant positive correlation with AREA_MN, PD, ED, and LPI metrics of compact buildings of 3-9 stories and industrial structures in both summer and winter. This pollutant had the same relationship with compact buildings of 1-3 stories so that it had a positive correlation with the AREA_MN and PD metrics in summer and the LPI metric in winter. It should be noted that $\mathrm{SO}_{2}$ had also a positive correlation with the LPI metric of large industrial warehouses in summer and the LPI and PD metrics of them in winter. AREA_MN and LPI metrics of scattered agricultural lands and grasslands had a negative correlation with $\mathrm{SO}_{2}$ in summer, which was also the case for the AREA_MN metric of scattered grasslands in winter. In addition to the above metrics, the PD and ED metrics of green spaces including trees (dense and scattered) had a negative correlation with $\mathrm{SO} 2$ in both seasons. The relationship between $\mathrm{NO}_{2}$ and the metrics defined for the configuration of land uses followed the same trends observed in relation to previous pollutants. However, the only difference was that AREA_MN, PD, and ED metrics of compact buildings of 3-9 stories and 1-3 stories and industrial structures had a positive correlation with this pollutant in summer. This correlation was more considerable in winter and the significant positive correlation could also be seen with regard to the LPI metric. Industrial warehouses also had a positive significant correlation with this pollutant in AREA_MN and PD metrics.

The investigation of the relationship between this pollutant and green spaces demonstrated that the AREA_MN, PD, and GYRATE_AM metrics of green spaces including trees (dense and scattered) and the ED and LPI metrics of scattered agricultural lands and grasslands had a negative correlation with this pollutant in both seasons. The relationship between the metrics determined for the configuration of land uses and the pollutants were such that the man-made land uses had a negative correlation with pollutants and the natural land uses had a positive correlation with them. However, the correlations recognized for $\mathrm{O}_{3}$ were similar to what was observed regarding the spatial composition of land uses. Built land uses (ED, LPI, and GYRATE_AM metrics) had a negative correlation with this pollutant while the LPI and AREA_MN metrics of green spaces including trees (dense and scattered) and the AREA_MN, LPI, and GYRATE_AM metrics of agricultural lands had a positive correlation with $\mathrm{O}_{3}$.

\section{Discussion}


The results of this study showed that the spatial pattern of built and man-made land uses, including compact mid-rise (2), compact low-rise (3), large low-rise (8), and heavy industry (10) had a positive correlation with $\mathrm{NO}_{2}, \mathrm{SO}_{2}$, and $\mathrm{CO}$ so that the larger the area of compact buildings with more stories, the higher the correlation between spatial pattern and pollutants. This finding is in line with the results of the study by Wang et al. (2017), indicating that compactness, height, and other spatial features of buildings affect significantly the direction of wind and its reduction. As a result, these spatial features can increase also the concentration of pollutants. In addition, one of the main reasons for the positive correlation between built and man-made land uses and the pollutant $\mathrm{CO}$ is the dispersion of land uses and the increase in travel demand, leading to increased concentration of this pollutant (Ou et al., 2013). On the other hand, in relation to industrial land uses, the presence of factories and heating systems in addition to vehicles has a great impact on the increased concertation of $\mathrm{NO}_{2}$. This positive correlation has also been shown in previous studies (Cárdenas Rodríguez et al., 2016; King et al., 2014; McCarty \& Kaza, 2015). Generally, due to the phenomenon of air inversion and the heavy cold weather that causes the air to not rise in winter, the concentration of pollutants increases and the correlation between pollutants and manmade land uses is intensified. In contrast, the correlation between these land uses with $\mathrm{O}_{3}$ was negative. As this pollutant is a secondary element and is created by the reactions between volatile organic compounds, $\mathrm{NO}_{2}$, and sunlight, it has a stronger correlation with land uses in summer when the angle of sunlight is more vertical.

A negative correlation was found between spatial patterns of green spaces, including dense trees $(A)$, scattered trees (B), bush and scrub (C), and low plants (D), and the pollutants $\mathrm{NO}_{2}, \mathrm{SO}_{2}$, and CO. In line with the findings of the study by $\mathrm{Ku}(2020)$, the investigation of the spatial configuration of such land uses showed that the increased PD of trees led to a reduced concentration of pollutants. This can be due to increased evapotranspiration and more photosynthesis in trees than other plants (Cao et al., 2010; Lin \& Xu, 2016; Zhang et al., 2009). In general, green spaces including more trees had a stronger inverse relationship with $\mathrm{NO}_{2}, \mathrm{SO}_{2}$, and $\mathrm{CO}$ in summer. However, as in the case of man-made land uses, the relationship between green spaces and $\mathrm{O}_{3}$ was different. It should be noted that this pollutant had a negative correlation with agricultural land uses in summer due to the presence of various plants and such a correlation could not be seen in winter due to lack of plants.

\section{Conclusions}

Using landscape metrics, including class area (CA), mean patch area (AREA_MN), patch density (PD), edge density (ED), largest patch index (LPI), and area-weighted radius of gyration (GYRATE_AM), the present study aimed to investigate the relationship between spatial patterns of various urban land uses and the pollutants $\mathrm{NO}_{2}, \mathrm{SO}_{2}, \mathrm{CO}$, and $\mathrm{O}_{3}$ in summer 2020 and winter 2021 in Tehran. To generate land use maps, LCZ scheme was used and 8 types of land uses, including compact mid-rise (2), compact low-rise (3), large low-rise (8), heavy industry (10), dense trees (A), scattered trees (B), bush and scrub (C), and low plants (D), were determined. The Sentinel-5P satellite images were employed to extract data related to the considered pollutants. 
The findings of this study are in line with the results of the studies by Halim et al. (2020), Xu et al. (2016), and Zhu et al. (2019) in the field of man-made land uses and the results of the research by Civerolo et al. (2000), Huang and Du (2018), and Irga et al. (2015) in the field of green spaces. The results showed that the spatial composition and configuration of man-made land uses, including the classes of compact midrise (2), compact low-rise (3), large low-rise (8), and heavy industry (10), had a positive correlation with $\mathrm{NO}_{2}, \mathrm{SO}_{2}$, and $\mathrm{CO}$. They had a negative correlation with $\mathrm{O}_{3}$. The positive correlations were stronger in winter due to air inversion, especially in the land uses of compact mid-rise and heavy industry. Regarding green spaces, which included the classes of dense trees (A), scattered trees (B), bush and scrub $(C)$, and low plants (D), the relationships were in contrast to those observed in the case of man-made land uses. In other words, these lands had a negative correlation with $\mathrm{NO}_{2}, \mathrm{SO}_{2}$, and $\mathrm{CO}$ and a positive correlation with $\mathrm{O}_{3}$. These correlations were much stronger in green spaces with dense trees and in summer due to the increased density of the plants and more photosynthesis.

Based on the models used, the relationship between spatial patterns of urban land uses and air pollutants was determined. The results obtained show that quantitative analyses can help to develop more complex strategies and scenarios in future research. Thus, in addition to the factors studied, such factors as traffic volume, population density, confinement ratio (street height-to-width ratio), and access to public transportation and climatic factors such as changes in temperature, rainfall, humidity, and wind may affect air quality and should be considered.

\section{Declarations}

\section{Funding}

The authors declare that no funds, grants, or other support were received during the preparation of this manuscript.

\section{Competing Interests}

The authors have no relevant financial or non-financial interests to disclose.

\section{Author Contributions}

All authors contributed to the study conception and design. Material preparation, data collection and analysis were performed by Soheil Gheshlaghpoor, Seyedeh Sanaz Abedi and Masoumeh Moghbel. The first draft of the manuscript was written by Soheil Gheshlaghpoor and all authors commented on previous versions of the manuscript. All authors read and approved the final manuscript.

\section{Data Availability}

The datasets generated during and/or analysed during the current study are available from the corresponding author on reasonable request. 


\section{References}

1. Alexander, P. J., \& Mills, G. (2014). Local Climate Classification and Dublin's Urban Heat Island. Atmosphere, 5(4), 755-774. https://www.mdpi.com/2073-4433/5/4/755

2. Alexander, P. J., Mills, G., \& Fealy, R. (2015). Using LCZ data to run an urban energy balance model. Urban Climate, 13, 14-37. https://doi.org/https://doi.org/10.1016/j.uclim.2015.05.001

3. Alvarez-Mendoza, C. I., Teodoro, A. C., Torres, N., \& Vivanco, V. (2019). Assessment of Remote Sensing Data to Model PM10 Estimation in Cities with a Low Number of Air Quality Stations: A Case of Study in Quito, Ecuador. Environments, 6(7), 85. https://www.mdpi.com/2076-3298/6/7/85

4. Amani, M., Ghorbanian, A., Ahmadi, S. A., Kakooei, M., Moghimi, A., Mirmazloumi, S. M., Moghaddam, S. H. A., Mahdavi, S., Ghahremanloo, M., Parsian, S., Wu, Q., \& Brisco, B. (2020). Google Earth Engine Cloud Computing Platform for Remote Sensing Big Data Applications: A Comprehensive Review. IEEE Journal of Selected Topics in Applied Earth Observations and Remote Sensing, 13, 5326-5350. https://doi.org/10.1109/JSTARS.2020.3021052

5. Basu, B., Alam, M. S., Ghosh, B., Gill, L., \& McNabola, A. (2019). Augmenting limited background monitoring data for improved performance in land use regression modelling: Using support vector regression and mobile monitoring. Atmospheric Environment, 201, 310-322.

https://doi.org/https://doi.org/10.1016/j.atmosenv.2018.12.048

6. Bechtel, B., \& Daneke, C. (2012). Classification of Local Climate Zones Based on Multiple Earth Observation Data. IEEE Journal of Selected Topics in Applied Earth Observations and Remote Sensing, 5(4), 1191-1202. https://doi.org/10.1109/JSTARS.2012.2189873

7. Bechtel, B., See, L., Mills, G., \& Foley, M. (2016). Classification of Local Climate Zones Using SAR and Multispectral Data in an Arid Environment. IEEE Journal of Selected Topics in Applied Earth Observations and Remote Sensing, 9(7), 3097-3105. https://doi.org/10.1109/JSTARS.2016.2531420

8. Bokwa, A., Hajto, M. J., Walawender, J. P., \& Szymanowski, M. (2015). Influence of diversified relief on the urban heat island in the city of Kraków, Poland. Theoretical and Applied Climatology, 122(1), 365382. https://doi.org/10.1007/s00704-015-1577-9

9. Cao, X., Onishi, A., Chen, J., \& Imura, H. (2010). Quantifying the cool island intensity of urban parks using ASTER and IKONOS data. Landscape and Urban Planning, 96(4), 224-231. https://doi.org/https://doi.org/10.1016/j.landurbplan.2010.03.008

10. Cárdenas Rodríguez, M., Dupont-Courtade, L., \& Oueslati, W. (2016). Air pollution and urban structure linkages: Evidence from European cities. Renewable and Sustainable Energy Reviews, 53, 1-9. https://doi.org/https://doi.org/10.1016/j.rser.2015.07.190

11. Civerolo, K. L., Sistla, G., Rao, S. T., \& Nowak, D. J. (2000). The effects of land use in meteorological modeling: implications for assessment of future air quality scenarios. Atmospheric Environment, 34(10), 1615-1621. https://doi.org/https://doi.org/10.1016/S1352-2310(99)00393-3

12. Conrad, O., Bechtel, B., Bock, M., Dietrich, H., Fischer, E., Gerlitz, L., Wehberg, J., Wichmann, V., \& Böhner, J. (2015). System for Automated Geoscientific Analyses (SAGA) v. 2.1.4. Geosci. Model Dev., 
8(7), 1991-2007. https://doi.org/10.5194/gmd-8-1991-2015

13. Danylo, O., See, L., Bechtel, B., Schepaschenko, D., \& Fritz, S. (2016). Contributing to WUDAPT: A Local Climate Zone Classification of Two Cities in Ukraine. IEEE Journal of Selected Topics in Applied Earth Observations and Remote Sensing, 9(5), 1841-1853.

https://doi.org/10.1109/JSTARS.2016.2539977

14. Das, M., \& Das, A. (2020). Assessing the relationship between local climatic zones (LCZs) and land surface temperature (LST) - A case study of Sriniketan-Santiniketan Planning Area (SSPA), West Bengal, India. Urban Climate, 32, 100591. https://doi.org/https://doi.org/10.1016/j.uclim.2020.100591

15. Du, N., Ottens, H., \& Sliuzas, R. (2010). Spatial impact of urban expansion on surface water bodies-A case study of Wuhan, China. Landscape and Urban Planning, 94(3), 175-185. https://doi.org/https://doi.org/10.1016/j.landurbplan.2009.10.002

16. Emmanuel, R., \& Krüger, E. (2012). Urban heat island and its impact on climate change resilience in a shrinking city: The case of Glasgow, UK. Building and Environment, 53, 137-149. https://doi.org/https://doi.org/10.1016/j.buildenv.2012.01.020

17. Fang, C., Liu, H., Li, G., Sun, D., \& Miao, Z. (2015). Estimating the Impact of Urbanization on Air Quality in China Using Spatial Regression Models. Sustainability, 7(11), 15570-15592. https://www.mdpi.com/2071-1050/7/11/15570

18. Fernández-Pacheco, V. M., López-Sánchez, C. A., Álvarez-Álvarez, E., López, M. J. S., García-Expósito, L., Yudego, E. A., \& Carús-Candás, J. L. (2018). Estimation of PM10 Distribution using Landsat5 and Landsat8 Remote Sensing. Proceedings, 2(23), 1430. https://www.mdpi.com/2504-3900/2/23/1430

19. Geletič, J., Lehnert, M., \& Dobrovolný, P. (2016). Land Surface Temperature Differences within Local Climate Zones, Based on Two Central European Cities. Remote Sensing, 8(10), 788. https://www.mdpi.com/2072-4292/8/10/788

20. Gómez-Baggethun, E., \& Barton, D. N. (2013). Classifying and valuing ecosystem services for urban planning. Ecological Economics, 86, 235-245.

https://doi.org/https://doi.org/10.1016/j.ecolecon.2012.08.019

21. Halim, N. D. A., Latif, M. T., Mohamed, A. F., Maulud, K. N. A., Idrus, S., Azhari, A., Othman, M., \& Sofwan, N. M. (2020). Spatial assessment of land use impact on air quality in mega urban regions, Malaysia. Sustainable Cities and Society, 63, 102436. https://doi.org/https://doi.org/10.1016/j.scs.2020.102436

22. Hien, P. D., Men, N. T., Tan, P. M., \& Hangartner, M. (2020). Impact of urban expansion on the air pollution landscape: A case study of Hanoi, Vietnam. Science of The Total Environment, 702, 134635. https://doi.org/https://doi.org/10.1016/j.scitotenv.2019.134635

23. Hoek, G., Brunekreef, B., Goldbohm, S., Fischer, P., \& van den Brandt, P. A. (2002). Association between mortality and indicators of traffic-related air pollution in the Netherlands: a cohort study. The Lancet, 360(9341), 1203-1209. https://doi.org/https://doi.org/10.1016/S0140-6736(02)11280-3 
24. Hopke, P. K., Cohen, D. D., Begum, B. A., Biswas, S. K., Ni, B., Pandit, G. G., Santoso, M., Chung, Y.-S., Davy, P., Markwitz, A., Waheed, S., Siddique, N., Santos, F. L., Pabroa, P. C. B., Seneviratne, M. C. S., Wimolwattanapun, W., Bunprapob, S., Vuong, T. B., Duy Hien, P., \& Markowicz, A. (2008). Urban air quality in the Asian region. Science of The Total Environment, 404(1), 103-112.

https://doi.org/https://doi.org/10.1016/j.scitotenv.2008.05.039

25. Huang, Y.-K., Luvsan, M.-E., Gombojav, E., Ochir, C., Bulgan, J., \& Chan, C.-C. (2013). Land use patterns and SO2 and NO2 pollution in Ulaanbaatar, Mongolia. Environmental Research, 124, 1-6. https://doi.org/https://doi.org/10.1016/j.envres.2013.02.006

26. Huang, Z., \& Du, X. (2018). Urban land expansion and air pollution: evidence from China. Journal of Urban Planning and Development, 144(4), 05018017.

27. Irga, P. J., Burchett, M. D., \& Torpy, F. R. (2015). Does urban forestry have a quantitative effect on ambient air quality in an urban environment? Atmospheric Environment, 120, 173-181. https://doi.org/https://doi.org/10.1016/j.atmosenv.2015.08.050

28. Kerle, N., Janssen, L. L., \& Huurneman, G. C. (2004). Principles of remote sensing. ITC, Educational textbook series, 2, 250.

29. King, K. L., Johnson, S., Kheirbek, I., Lu, J. W. T., \& Matte, T. (2014). Differences in magnitude and spatial distribution of urban forest pollution deposition rates, air pollution emissions, and ambient neighborhood air quality in New York City. Landscape and Urban Planning, 128, 14-22. https://doi.org/https://doi.org/10.1016/j.landurbplan.2014.04.009

30. Ku, C.-A. (2020). Exploring the Spatial and Temporal Relationship between Air Quality and Urban Land-Use Patterns Based on an Integrated Method. Sustainability, 12(7). https://doi.org/10.3390/su12072964

31. Leconte, F., Bouyer, J., Claverie, R., \& Pétrissans, M. (2015). Estimation of spatial air temperature distribution at sub-mesoclimatic scale using the LCZ scheme and mobile measurements. Proceedings of the 9th International Conference on Urban Climate (ICUC9) jointly with 12th Symposium on the Urban Environment, Toulouse, France,

32. Lehnert, M., Geletič, J., Husák, J., \& Vysoudil, M. (2015). Urban field classification by “local climate zones" in a medium-sized Central European city: the case of Olomouc (Czech Republic). Theoretical and Applied Climatology, 122(3), 531-541. https://doi.org/10.1007/s00704-014-1309-6

33. Lelovics, E., Unger, J., Gál, T., \& Gál, C. V. (2014). Design of an urban monitoring network based on Local Climate Zone mapping and temperature pattern modelling. Climate Research, 60(1), 51-62. https://www.int-res.com/abstracts/cr/v60/n1/p51-62/

34. Li, H., \& Wu, J. (2004). Use and misuse of landscape indices. Landscape Ecology, 19(4), 389-399. https://doi.org/10.1023/B:LAND.0000030441.15628.d6

35. Li, X., Zhou, W., Ouyang, Z., Xu, W., \& Zheng, H. (2012). Spatial pattern of greenspace affects land surface temperature: evidence from the heavily urbanized Beijing metropolitan area, China. Landscape Ecology, 27(6), 887-898. https://doi.org/10.1007/s10980-012-9731-6 
36. Lin, Z., \& Xu, H. (2016, 4-6 July 2016). A study of Urban heat island intensity based on "local climate zones": A case study in Fuzhou, China. 2016 4th International Workshop on Earth Observation and Remote Sensing Applications (EORSA),

37. Liu, H.-L., \& Shen, Y.-S. (2014). The Impact of Green Space Changes on Air Pollution and Microclimates: A Case Study of the Taipei Metropolitan Area. Sustainability, 6(12), 8827-8855. https://www.mdpi.com/2071-1050/6/12/8827

38. McCarty, J., \& Kaza, N. (2015). Urban form and air quality in the United States. Landscape and Urban Planning, 139, 168-179. https://doi.org/https://doi.org/10.1016/j.landurbplan.2015.03.008

39. McGarigal, K. (2015). FRAGSTATS help. University of Massachusetts: Amherst, MA, USA, 182.

40. Meng, X., Fu, Q., Ma, Z., Chen, L., Zou, B., Zhang, Y., Xue, W., Wang, J., Wang, D., Kan, H., \& Liu, Y. (2016). Estimating ground-level PM10 in a Chinese city by combining satellite data, meteorological information and a land use regression model. Environmental Pollution, 208, 177-184. https://doi.org/https://doi.org/10.1016/j.envpol.2015.09.042

41. Moghbel, M., \& Erfanian Salim, R. (2017). Environmental benefits of green roofs on microclimate of Tehran with specific focus on air temperature, humidity and CO2 content. Urban Climate, 20, 46-58. https://doi.org/https://doi.org/10.1016/j.uclim.2017.02.012

42. Ng, E. (2009). Policies and technical guidelines for urban planning of high-density cities - air ventilation assessment (AVA) of Hong Kong. Building and Environment, 44(7), 1478-1488. https://doi.org/https://doi.org/10.1016/j.buildenv.2008.06.013

43. Nowak, D. J., Civerolo, K. L., Trivikrama Rao, S., Gopal, S., Luley, C. J., \& E. Crane, D. (2000). A modeling study of the impact of urban trees on ozone. Atmospheric Environment, 34(10), 1601-1613. https://doi.org/https://doi.org/10.1016/S1352-2310(99)00394-5

44. Nowak, D. J., Crane, D. E., \& Stevens, J. C. (2006). Air pollution removal by urban trees and shrubs in the United States. Urban Forestry \& Urban Greening, 4(3), 115-123. https://doi.org/https://doi.org/10.1016/j.ufug.2006.01.007

45. Ou, J., Liu, X., Li, X., \& Chen, Y. (2013). Quantifying the relationship between urban forms and carbon emissions using panel data analysis. Landscape Ecology, 28(10), 1889-1907. https://doi.org/10.1007/s10980-013-9943-4

46. Parry, M., Parry, M. L., Canziani, O., Palutikof, J., Van der Linden, P., \& Hanson, C. (2007). Climate change 2007-impacts, adaptation and vulnerability: Working group II contribution to the fourth assessment report of the IPCC (Vol. 4). Cambridge University Press.

47. Peng, J., Wang, Y., Zhang, Y., Wu, J., Li, W., \& Li, Y. (2010). Evaluating the effectiveness of landscape metrics in quantifying spatial patterns. Ecological Indicators, 10(2), 217-223.

https://doi.org/https://doi.org/10.1016/j.ecolind.2009.04.017

48. Riitters, K. H., O'Neill, R. V., Hunsaker, C. T., Wickham, J. D., Yankee, D. H., Timmins, S. P., Jones, K. B., \& Jackson, B. L. (1995). A factor analysis of landscape pattern and structure metrics. Landscape Ecology, 10(1), 23-39. https://doi.org/10.1007/BF00158551 
49. Romero, H., Ihl, M., Rivera, A., Zalazar, P., \& Azocar, P. (1999). Rapid urban growth, land-use changes and air pollution in Santiago, Chile. Atmospheric Environment, 33(24), 4039-4047. https://doi.org/https://doi.org/10.1016/S1352-2310(99)00145-4

50. Sannigrahi, S., Pilla, F., Basu, B., Basu, A. S., \& Molter, A. (2020). Examining the association between socio-demographic composition and COVID-19 fatalities in the European region using spatial regression approach. Sustainable Cities and Society, 62, 102418. https://doi.org/https://doi.org/10.1016/j.scs.2020.102418

51. She, Q., Peng, X., Xu, Q., Long, L., Wei, N., Liu, M., Jia, W., Zhou, T., Han, J., \& Xiang, W. (2017). Air quality and its response to satellite-derived urban form in the Yangtze River Delta, China. Ecological Indicators, 75, 297-306. https://doi.org/https://doi.org/10.1016/j.ecolind.2016.12.045

52. Stewart, I. D., \& Oke, T. R. (2010). Thermal differentiation of local climate zones using temperature observations from urban and rural field sites. Preprints, 9th Symposium, on Urban Environment, Keystone, $\mathrm{CO}$,

53. Stewart, I. D., \& Oke, T. R. (2012). Local climate zones for urban temperature studies. Bulletin of the American Meteorological Society, 93(12), 1879-1900.

54. Tao, W., Liu, J., Ban-Weiss, G., Hauglustaine, D., Zhang, L., Zhang, Q., Cheng, Y., Yu, Y., \& Tao, S. (2015). Effects of urban land expansion on the regional meteorology and air quality of eastern China. Atmospheric Chemistry and Physics, 15(15), 8597-8614.

55. Veefkind, J. P., Aben, I., McMullan, K., Förster, H., de Vries, J., Otter, G., Claas, J., Eskes, H. J., de Haan, J. F., Kleipool, Q., van Weele, M., Hasekamp, O., Hoogeveen, R., Landgraf, J., Snel, R., Tol, P., Ingmann, P., Voors, R., Kruizinga, B., Vink, R., Visser, H., \& Levelt, P. F. (2012). TROPOMI on the ESA Sentinel-5 Precursor: A GMES mission for global observations of the atmospheric composition for climate, air quality and ozone layer applications. Remote Sensing of Environment, 120, 70-83.

https://doi.org/https://doi.org/10.1016/j.rse.2011.09.027

56. Wang, B., Cot, L. D., Adolphe, L., Geoffroy, S., \& Sun, S. (2017). Cross indicator analysis between wind energy potential and urban morphology. Renewable Energy, 113, 989-1006. https://doi.org/https://doi.org/10.1016/j.renene.2017.06.057

57. Wang, S., Zeng, J., Huang, Y., Shi, C., \& Zhan, P. (2018). The effects of urbanization on $\mathrm{CO} 2$ emissions in the Pearl River Delta: A comprehensive assessment and panel data analysis. Applied Energy, 228, 1693-1706. https://doi.org/https://doi.org/10.1016/j.apenergy.2018.06.155

58. Wei, Y. D., \& Ye, X. (2014). Urbanization, urban land expansion and environmental change in China. Stochastic Environmental Research and Risk Assessment, 28(4), 757-765. https://doi.org/10.1007/s00477-013-0840-9

59. Weng, Q., \& Yang, S. (2006). Urban Air Pollution Patterns, Land Use, and Thermal Landscape: An Examination of the Linkage Using GIS. Environmental Monitoring and Assessment, 117(1), 463-489. https://doi.org/10.1007/s10661-006-0888-9

60. Xian, G. (2007). Analysis of impacts of urban land use and land cover on air quality in the Las Vegas region using remote sensing information and ground observations. International Journal of Remote 
Sensing, 28(24), 5427-5445.

61. Xu, G., Jiao, L., Zhao, S., Yuan, M., Li, X., Han, Y., Zhang, B., \& Dong, T. (2016). Examining the Impacts of Land Use on Air Quality from a Spatio-Temporal Perspective in Wuhan, China. Atmosphere, 7(5), 62. https://www.mdpi.com/2073-4433/7/5/62

62. Zahari, M., Majid, M., Ho, C., Kurata, G., Nadhirah, N., \& Irina, S. (2016). Relationship between land use composition and PM concentrations in Iskandar Malaysia. Clean Technologies \& Environmental Policy, 18(8).

63. Zebardast, E., \& Riazi, H. (2015). Built Environment Features and its Impact on Air Pollution (Case Study: Surrounding Areas of Fourteen Air Quality Monitoring Stations in Tehran).

64. Zhang, B., Zhang, M., Kang, J., Hong, D., Xu, J., \& Zhu, X. (2019). Estimation of PMx Concentrations from Landsat 8 OLI Images Based on a Multilayer Perceptron Neural Network. Remote Sensing, 11(6), 646. https://www.mdpi.com/2072-4292/11/6/646

65. Zhang, X., Zhong, T., Feng, X., \& Wang, K. (2009). Estimation of the relationship between vegetation patches and urban land surface temperature with remote sensing. International Journal of Remote Sensing, 30(8), 2105-2118. https://doi.org/10.1080/01431160802549252

66. Zhou, W., Huang, G., \& Cadenasso, M. L. (2011). Does spatial configuration matter? Understanding the effects of land cover pattern on land surface temperature in urban landscapes. Landscape and Urban Planning, 102(1), 54-63. https://doi.org/https://doi.org/10.1016/j.landurbplan.2011.03.009

67. Zhu, Z., Wang, G., \& Dong, J. (2019). Correlation Analysis between Land Use/Cover Change and Air Pollutants-A Case Study in Wuyishan City. Energies, 12(13), 2545. https://www.mdpi.com/19961073/12/13/2545

\section{Figures}




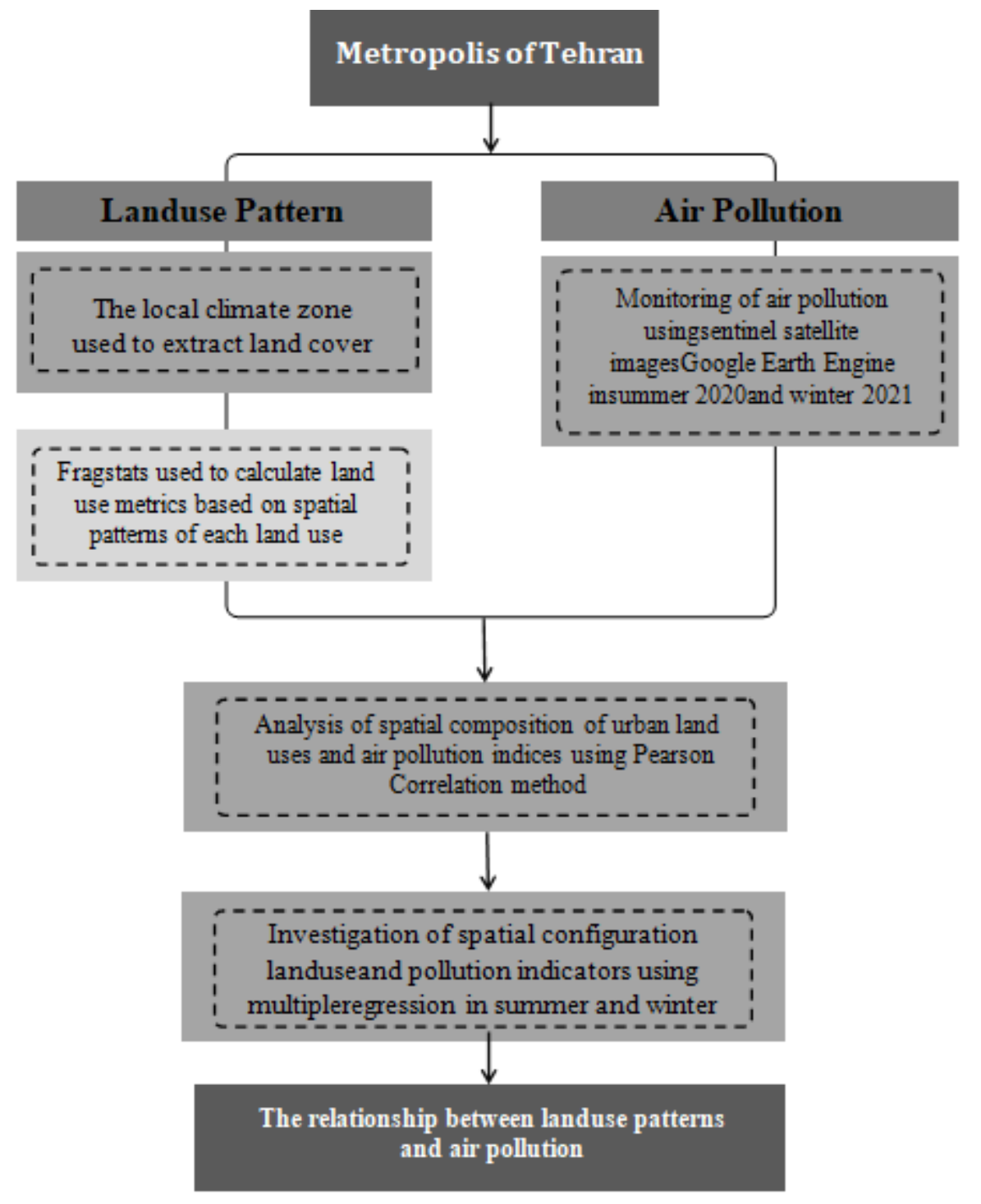

\section{Figure 1}

Analytical framework of the research 


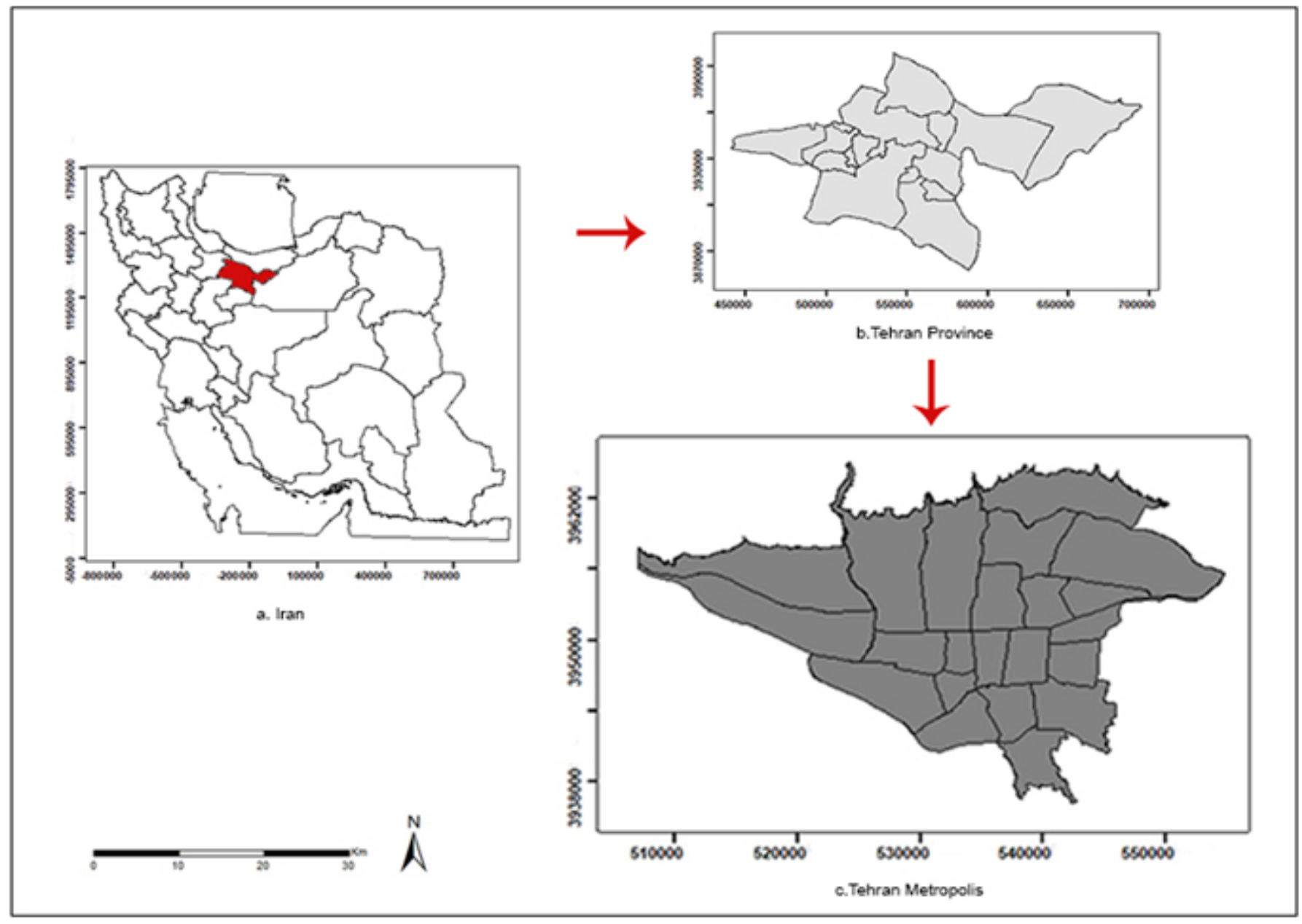

Figure 2

study area 


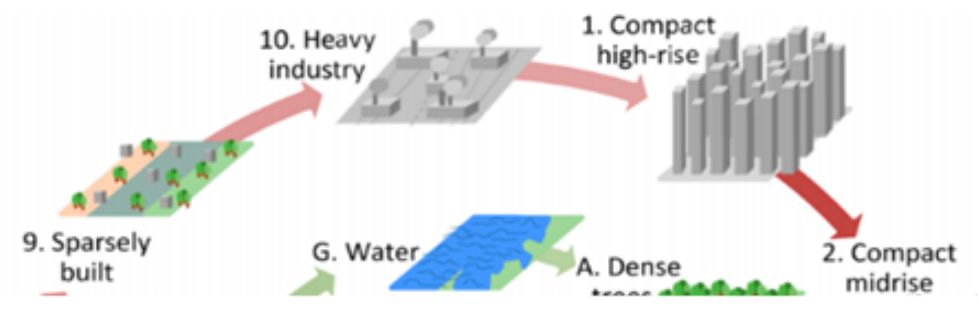

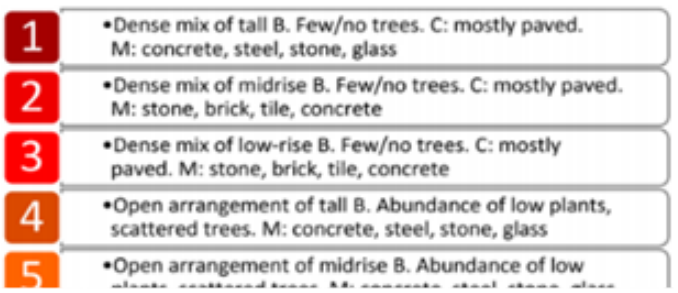

\section{Figure 3}

Urban (1-10) and natural (A-G) LCZ types and their characteristics (Stewart \& Oke, 2012)and colour code used in the WUDAPT framework. B: Buildings; C: cover; M: materials; F: function; Tall: >10 stories, Mid-rise: 3-9 stories, Low: 1-3 stories; used in this study (LCZ 2, 3, 8 and 10; LCZ A, B, C, D). 


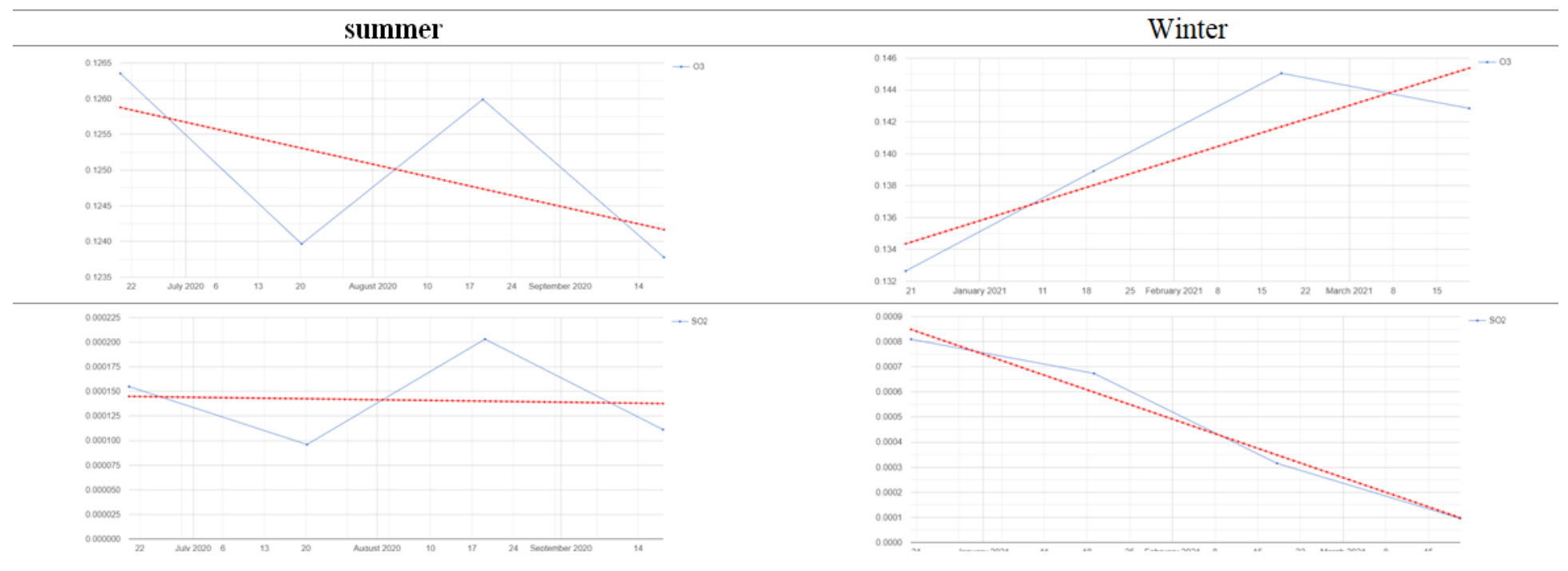

Figure 4

air pollutants changetrend

\section{Supplementary Files}

This is a list of supplementary files associated with this preprint. Click to download.

- Apendix.docx 